\title{
Mathematics learning media development of based computer on translation context in senior high school
}

\author{
Arifa Rahmi ${ }^{1}$, Armiati ${ }^{2}$ dan Hendra Syarifuddin ${ }^{3}$ \\ ${ }^{123}$ Universitas Negeri Padang, Padang - Indonesia, (rahmiarifa31@gmail.com)
}

\begin{abstract}
Students faced the difficulty in understanding concept and interpreting of direction of a transformed geometry object, especially translation context. To solved this students difficulty need mathematics learning media which able to clarify translation context and provide them opportunities to learn actively. The aim of this research to know the characteristics and description of mathematics learning media of based computer which is should be valid, practical and effective on translation context in improving the students learning outcomes and their activities. This research wasusingresearch development which apply Plomp model. This model consist of three phase namely initial preliminary research, development or prototyping stage and assessment phase. This research found that mathematics learning media of based computer was valid, practical and effective.
\end{abstract}

Keyword: mathematics learning media, computer, translation.

\section{Introduction}

One part of geometry concept that study about change in position, size or shape is transformation. In his research, Rollick [1] reaserch said that students faced the difficulty in understanding concept and identifying transformation include translation, rotation and its combination. Reaserch of Morris \& Paulsen's [2] too said that few student have been able to do transformation for simple geometry object, but difficulty to solve complex problems. The case is also found in Indonesia, for example at MAN 1 Bukittinggi. Students faced the difficulty to in understanding concept and interpreting direction of transformed geometry object and describing the proof algebraically. This statement was supported by the results daily test of students grade XII on transformation context of the academic year $2015 / 2016$. Less of $50 \%$ students' have value are below the minimum completion criteria. This shows that the students learning outcomes on geometry transformation context was still low.

Some mathematics teachers stated that students using the mathematics book of Kemendikbud RI. In transformation context, especially translation, change of position, shape or size the transformed geometry object marked with arrows. The most of students have difficulty understanding the mark correctly. Thus, the students difficulties in understanding the direction of geometry object shift and proof algebraically.The students need visualization on translation context that more practical, effective and learning time can be optimized.This need can be fulfilled by based computer media. Learning become varied, translation context become more clear through animation dan learning time more eficiently. In his research, Panorkou [3] said that provide learning media for students be able to 
explore and improve to understand the transformation concept. Nadira [4] reaserch too said that learning media can attract to interest and facilitate the students to learn mathematics. Learning media as a tool of learn that clarify the presentation of information in learning process. Changes in position, size or shape of an object is indicated by animation movement.

Learning media have designed in this research was mathematics learning media of based computer usedmacromedia flash 8 program. The subject matter was begin by giving the problems. Then, the studens observe the illustrations on learning media. The students resolve the questions on learning media for help them to understand the concept lesson. The students collect information fromquestions to discuss and analyze the answers. The results of student the answers are deliveres in front of the class, so that learning time oriented to their activities.This research was designed dan developed learning media to improve the students learning outcomes and their activities.This research development is titled "mathematics learning media of based computer on translation context in senior high school".

\section{Method}

Type of research applied is research development which using Plomp model. This model consist of three phase namely initial preliminary research, development or prototyping stage and assessment phase.

Preliminary research is done by necessity analysis, curriculum analysis, concept analysis and student analysis. Data on necessity analysis can be obtained from mathematics teachers interview and students questionnaires. Curriculum analysis is done by analyze the mathematics syllabus in senior high school of the second semester. Concept analysis is done by identify dan systematically arrange mathematical concept. The concept of material discussed in this research is translation. Then, student analysis is done to know the characteristics of students include academic abilty, ages, learning tendency and pleasure of students' color.

Prototyping stage is done by design mathematics learning media based on Tessmer's formative evaluation. This phase consist of self evaluation, expert review, one-to-one evaluation, small group evaluation dan field test. The students involved in this evaluation are grade XI IPA in MAN 1 Bukittinggi.

Assessment phase was done in field test phase for grade XI IPA in MAN 1 Bukittinggi. Mathematics teacher who implement learning and students use learning media of based computer on translation context.This phase to know practicality and effectiveness for mathematics learning media of based computer to improve students learning outcomes and their activities.

\section{Results and Discussion}

Preliminary research is done by analyze the mathematics syllabus in senior high school of the second semester. The basic competencies are appropriated to syllabus on the 2013 curriculum. The time allocation set on translation context in syllabus is 2 lesson hours @ 45 menit. Translation context are started with a simpler concept untill to complex concept. This context discusses the characteristic and concept translation. Translation change the position of a transformed geometry object by moving it in certain direction and distance.

The most of student is more likely learning activity together. So then, the students are grouped in learning process using media. The group's are appropriated by academic abilty, including high, medium and low ability. This criteria selection is helped by teacher and the value of semester mid in the academic year 2016/2017. Generally, grade XI students are 16-17 years old. Piaget's cognitive developmental theory in Darmadi [5] said that the students have been able to think abstractly, 
logically, conclutions dan develop hypotheses. In the fact that the students need learning media to clarify the subject matter.

All of students can operate a computer and like learn using computer. The teachers and students responded positively when they are offered learning media of ased computer. Designe of learning media recommended by teachers and students istranslation context completeness, students can be self learning, priority the utilization, ease of uses, attractiveness of display such as image, animations and colors, menus and navigation buttons, as well learning time can be maximized. The students preference for the colors based on color psychology. According to Waikins (2001) in Nugroho [6], the color that many people love is blue. According to the questionnaire, the most students choose blue as their favorite color. Thus, blue as the dominant color for learning media.

Characteristics of learning media design include three aspects, namely content, language, as well presentation and graphics. In the content aspect, translation context is presented systematically about characteristics and translation concept. Macromedia flash 8 program is used in design of learning media with following the scientific approach activities. In the language aspect, learning media uses communicative language, standard language and easily understood by students.

In the presentation and graphics aspect, first designed the flowchart and the storyboard of learning media. Systematics and structure of learning media consists of intro page, media cover, user identity, menus, user guidance, competence, translation context, evaluation, reference and profile. The learning media is equipped with various type fonts, such as Adobe Caslom Pro Bold, Berlin Sans FB Demi, Times New Roman, Comic Sans MS, Stencil and Bernard MT Condensed which is easy to read. The last step, learning media published in the windows projector (.exe) form, then it is burned into the disk compact. Example of learning media page design can be see in figur 1 .

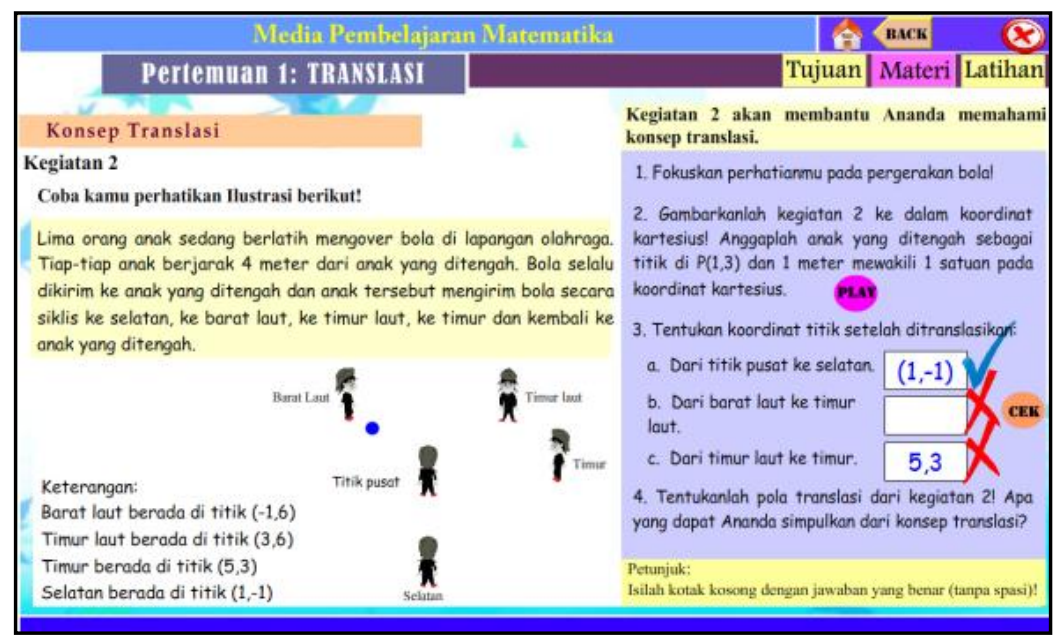

Figur 1. The Learning Media Design

In the picture 1, presented example of problems on the translation context. Students are asked to observe movement illustration of the ball on five children. The ball moving cyclically to south, northwest, northeast, east and back to the middle child (left side). From the illustration, the students solve the questions that exist in the learning media (right side). Then, the students collect information from illustrations or questions while discussing with friends or teachers.

In the question number 1 , the students focus their attention on the illustration. In the question number 2, the students draw the illustration in cartesian coordinates dan they can push PLAY button to show the figur 2. Example of cartesian coordinates page design can be see in figur 2 . 


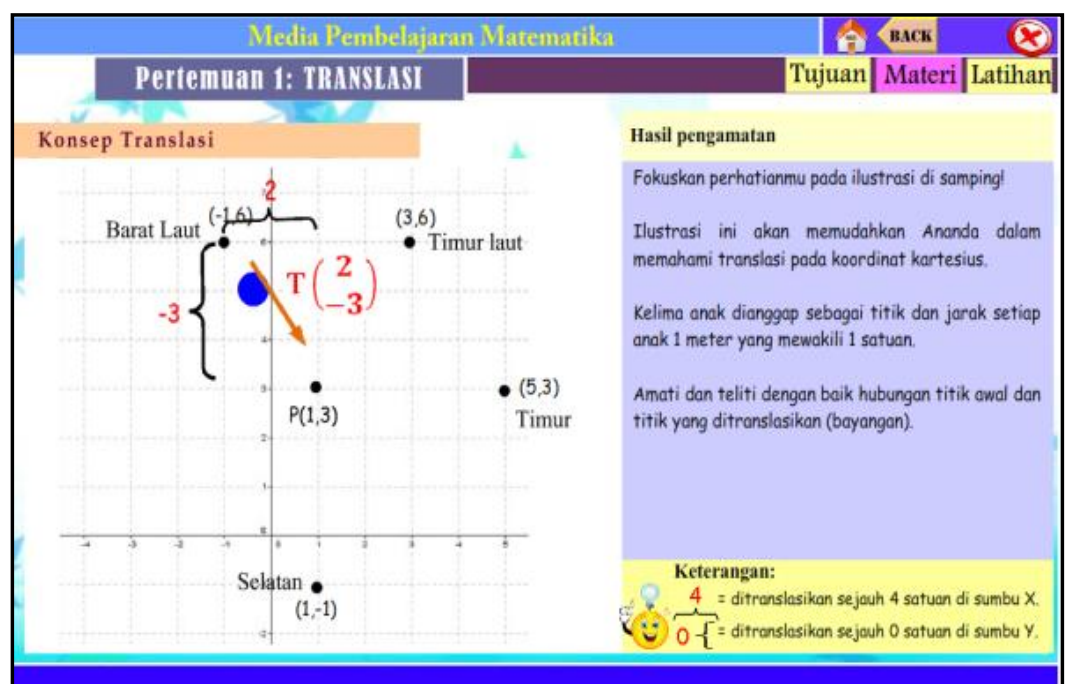

Figur 2. Cartesian Coordinates Design

In the figur 2 presents the animation movement at the cartesian coordinates of the northwest $(-1,6)$ to the central point $(1,3)$. The point moves as far as 2 units to the right in absis dan as far as 3 units down in ordinat. Thus, the students can determine the endpoint of displacement (visualization) by summing the starting point with its translation point.

In the question number 3 , the students determine the point coordinates after translated. If the students answers a. $(1,-1)$; b. $(3,6)$; and c. $(5,3)$ so then the learning media will respond to the answer with a blue check mark, but if the answer is wrong the media respond with a red cross sign. Then, the students analyze the answer, so that they get a conclusion from the subjects matter.The question number 4lead the students to make possible translational patterns, then they find common equations and conclusions. Results of the students' answers are conveyed in front of the class. The students' worksheet as facility in writing answers to the questions that exist in the learning media.

After finished mediawas designed, then evaluated based on Tessmer's formative evaluation, namely:

\section{a. Self evaluation}

Self evaluation aims to recheck the components of the learning media design. Errors that occur at this stage are typing words, layout, front size and navigation buttons. Repaired about sentences in the translation exercise "shifted 4 rows to the left and 2 rows back" to "shifted 4 to left and 2 to backwards". Repaired to colors of "YA" and "TIDAK" buttons become white color. The result of the improvement of learning media is called prototype 2 .

\section{b. Expert review}

The learning media validated by five experts (validator).Validators involved in the validation process are mathematics education experts, learning media experts and indonesian experts.Aspects assessed by the experts include content, language, as well presentation and graphics.Based on the validator's assessment, it is known that the learning medium meets the valid criteria. This shows the learning media has been arranged in a systematic, arranged standard language and easily understood by students.The learning media has been also appropriate to necessity of the students, pictures and animations is interesting, type and size of the proportional letters, layout accordingly and navigations easy to operate. During the validation process there are revisions suggested by validator, such as improved layout, type of posts and button hints on the cover page, as well as changing the position of each child on the translation concept. The result of the improvement of learning media is called prototype 3 . 


\section{c. One to one evaluation}

One to one evaluation was done by asking three students who meet the criteria of ability of high, medium and low. The students were grade XI IPA 4 in MAN 1 Bukittinggi. This phase is done face to face between researchs with students and performed alternately starting with students ability of high, medium and low. Implementation of this trial conducted five meetings.The three students use computer tolearn translation subject, while researchers will observe it. After learning activities, were conducted interview with the students. Revisions to this the learning media are improved background color questions with hints of questions, non functioning navigations and unfit animations. The result of the improvement of learning media is called prototype 4.

\section{d. Small group evaluation}

Small group evaluation was done by asking six students who meet the criteria of ability of high, medium and low. The students were devided into two groups, consisting of three high, medium and low ability.The students involved in this activity is XI IPA 4 in MAN 1 Bukittinggi.The learning activities adjust the lesson plan designed for the learning media.A small group evaluation was conducted in five meetings.This phase is done face to face between researchers with students. Researchers act as teachers and student using computers in translation context.

This evaluation was done to see the practice of learning media. Based on the results of interview, the students are more easily understand the translation context because the media can be played repeattedly when constrained. The students also argue that the learning media is easy to use, the sentence is clear and understood, in accordance with necessity of students and train the independence of learning.The learning media has clear illustrations, attractive pictures and animations quality, regular layout, varied colors, easy navigations to operate and alocation learning time efficient.The result questionnaire presentage of learning media by students after small group trial is $80,21 \%$ with very practical criteria.Thus, mathematics learning media of based computer on translation context has been considered practical and can be used properly.

The effectiveness was seen from the test after the students learn the translation context aid of learning media.The result presentage test of students who received the same or exceeded minimal criteria score $(\geq 75)$ was $83,33 \%$.Thus, mathematics learning media of based computer on translation context has been said to be effective, because more than $75 \%$ of students get the same or exceeded minimal criteria score.Researchers make improvements to get the learning media.The result of the improvement of learning media is called prototype 5 .

\section{Assessment stage}

Assessment phase was done in field test phase.The field test was done to grade XI IPA 1 as many as 34 people in MAN 1 Bukittinggi. During the field test, the mathematics teacher thaught with the learning media that the researcher had designed. The students use the computer to learn translation context aid of learning media. Schedule of learning implementation adjusted the lesson plan for five times meeting.The students are devided into seven groups, each consisting of four or five people. This phase to know practicality and effectiveness of learning media.Description of the results analysis of each instrument is ad follows:

a. Practicality test

The learning media is said to be practical if the teachers and the students can implement learn optimally. The result questionnaire presentage of learning media by teacher after field test is $91,00 \%$ with very practical criteria. Then, the result questionnaire presentage of learning media by student after field test is $83,75 \%$ with very practical criteria. Last, the result of interviews with teacher can be concluded that learning activities used learning media on translation context performed well. The learning media helps the students to understand the subject matter and the students become actively. The design of learning media is easy to understand, pictures or animations is interesting, layout 
accordingly, help present the subject matter and learning time efficient. Based on instrument of practicality on field test can be concluded that mathematics learning media of based computer on translation context has been considered practical and can be used properly.

b. Effectiveness test

The learning media is said to be effective whengiving influence to the students during process seen from students learning outcomes and their activities.Students learning outcomes seen through the test at the end of the learning process. Learning media is said to be effective when more than $75 \%$ of students get the same or exceeded minimal criteria score.

Tabel 1. < Students learning outcomes >

\begin{tabular}{cccc}
\hline & \multicolumn{2}{c}{ Mastery of Students } & Total \\
\cline { 2 - 4 } Total of Students & Completed $(\geq 75)$ & Not completed $(<75)$ & \\
\% & 28 & 6 & 34 \\
\hline
\end{tabular}

The result test of 34 students at this stage there are 28 students presentage of $83,33 \%$ said complete, meaning the students have obtained the same or exceeded minimal criteria score $(\geq 75)$. Then, there are 6 students presentage of $11,77 \%$ said not complete.

The students activities during learn to aid mathematics learning media of based computer to increase. This is indicated by the presentage of students activity equal or more than $50 \%$. The students have done activity that exist in the learning media, discussing, giving opinion, presenting the result of discussions, working on problems, as well the students are be calm and not make a fuss in the learning process. Thus, mathematics learning media of based computer on translation context has been effective to improve students learning outcomes and their activities.

\section{Conclusions}

This reseach has resulted in mathematics learning media of based computer on translation context. Based on the results of data analysis, it can be concluded that the learning media has been developed is valid, practical and effective. So then, the learning media can be used as a guide for teachers in implement learning to improve students learning outcomes and their activities.

\section{Acknowledgments}

This work was supported by Padang state University, master of mathematics educationdepartment. Also, thank's to headmasterand mathematics teachers at MAN 1 Bukittinggi who has allowed and facilitated the researchers to carry out the reseach.

\section{References}

Rollick, M. B. (2009). Toward a Deffinition of Reflection. JurnalMathematics Teaching in the Middle School. Vol 7.

Morris, T. \& R. Paulsen. (2011). Using Tracing Paper to Teach Transformation Geometry. Jurnal Amesa. ISBN 978-0-620-47379-8. Johannensberg: Amesa.

Panorkou, Nicole._. Developing Elementary Students' Reasoning of Geometric Transformations through Dynamic Animation. Montclair, USA: Montclair State University.

Nadira, Ifka Warda dan Utari Dewi. (2014). Pengembangan Media Pembelajaran Computer Assisted Instruction. Jurnal Mahasiswa Teknologi Pendidikan. Vol 2. Surabaya: Universitas Negeri Surabaya. 
Darmadi, H. (2017). Pengembangan Model dan Metode Pembelajaran dalam Dinamika Belajar Siswa. ISBN 978-692-802-935-5. Yogyakarta: Penerbit Gava Media.

Nugroho, Sarwo. (2015). Manajemen Warna dan Desain. Ed. 1. ISBN 978-979-29-5404-3. Yogyakarta: Andi Offset. 